\title{
Growth and breeding of a primitive stalked barnacle Leucolepas longa (Cirripedia: Scalpellomorpha: Eolepadidae: Neolepadinae) inhabiting a volcanic seamount off Papua New Guinea
}

\author{
V. Tunnicliffe* and A.J. Southward* ${ }^{\dagger \ddagger}$ \\ * Department of Biology, University of Victoria, Victoria, BC, Canada, V8W 3N5 \\ ${ }^{\dagger}$ Marine Biological Association, Citadel Hill, Plymouth, PL1 2PB, UK. ${ }^{\ddagger}$ Corresponding author, e-mail: ajs@mba.ac.uk
}

\begin{abstract}
A pedunculate barnacle, Leucolepas longa, occurs in densities over 1000 individuals $\mathrm{m}^{-2}$ on the summit of a small seamount near New Ireland, Papua New Guinea. Most of the population grows on vesicomyid clams projecting from sulphide-rich sediments, or on their dead shells, but the barnacle also settles on rock and on tubes of a vestimentiferan. Collections of several hundred barnacles allowed comparison of population and reproductive characteristics. The barnacle is a suspension feeder with a lightly-armoured stalk that can grow to $40 \mathrm{~cm}$ above the bottom. Growth appears to be rapid and both reproduction and recruitment are continuous. The barnacles brood egg masses within the capitular chamber and $46 \%$ of one sample was brooding. Lecithotrophic nauplii released upon retrieval to the surface were cultivated for 45 days. Metamorphosis to Stage IV yielded an actively swimming larva about $1 \mathrm{~mm}$ long overall, which still contained lipid reserves, indicating capacity for wide dispersal.
\end{abstract}

\section{INTRODUCTION}

Pedunculate, or stalked barnacles belonging to the Scalpellomorpha, are a recognizable component of the deep-sea benthos, but are infrequently encountered by dredging or by submersibles. Many species listed in the monograph by Zevina (1982) are quite rare or are known only singly. Exceptions include those scalpellomorphs that live close to hydrothermal vents, where population densities are usually higher than on the abyssal plain. Since the initial discovery of Neolepas zevinae Newman at vents on the northern East Pacific Rise (EPR) (Newman, 1979, 1985), related species are now known on the south EPR and off New Zealand (Jones, 1993; Buckeridge, 2000). Undescribed eolepad barnacles also exist in collections from vents in the western Pacific in the back-arc basins of Fiji, Lau, Manus, the Marianas and Okinawa (Ohta, 1990; Tufar, 1990; Hessler \& Lonsdale, 1991; Ikeya \& Yamaguchi, 1993; Desbruyères et al., 1994; Southward \& Newman, 1998). Eolepads recently reported from the Indian Ocean Ridge (IOR), the Pacific Antarctic Ridge (PAR), and the south Fiji Ridge also remain undescribed (Southward et al., 1997; personal communications from C.L. Van Dover, P. Stoffers, M. Türkay, T. Worthington, T. Yamaguchi).

Dense populations of barnacles are a feature of some western Pacific hydrothermal vents where both stalked and sessile types occur (Newman \& Yamaguchi, 1990; Tufar, 1990; Hessler \& Lonsdale, 1991; Ikeya \& Yamaguchi, 1993; Desbruyères et al., 1994; Newman \& Yamaguchi, 1995; Yamaguchi \& Newman, 1997a,b). The high biomass of these suspension-feeders suggests that they form an important component of the vent community. Occurrence at such high densities allows investigators to collect large samples without much damage to the habitat. Here, we report observations on an eolepad species (described as Leucolepas longa, Southward \& Jones, 2002) that was collected on a volcanic seamount off Papua New Guinea. The new information considerably augments the sparse information available on the biology of this unusual group of cirripedes. Bulk collections and in situ photographs provided observations of large numbers of individuals while the relatively shallow setting allowed retrieval of live animals and subsequent observations on developing larvae.

\section{MATERIALS AND METHODS \\ Study site}

Edison Seamount is located about $8 \mathrm{~km}$ south of Lihir Island, rising to $1450 \mathrm{~m}$ on the island slope (Figure 1). The geologic setting of the site is that of a rifted forearc as part of the Feni-Tabar island arc off Papua New Guinea. Current tectonic rifting is propagating north-east from the Manus Basin and is presumably the cause of volcanic activity in the Feni-Tabar island chain (Herzig \& Hannington, 1995). Hydrothermal activity is known in the Woodlark Basin (Scott \& Binns, 1995; Binns et al., 1997) and hydrothermal organisms have been recovered from the Manus Basin (Galkin, 1997). New Britain and New Ireland, in their present configuration, appear to form a barrier to dispersal of deep-water vent organisms to the Lihir area from these basins, thus distinct species occur either side (Southward \& Galkin, 1997). Herzig et al. (1998) document seismic activity in the region of Lihir Island characteristic of extensional spreading that may induce crustal fluid circulation. Geothermal activity is 

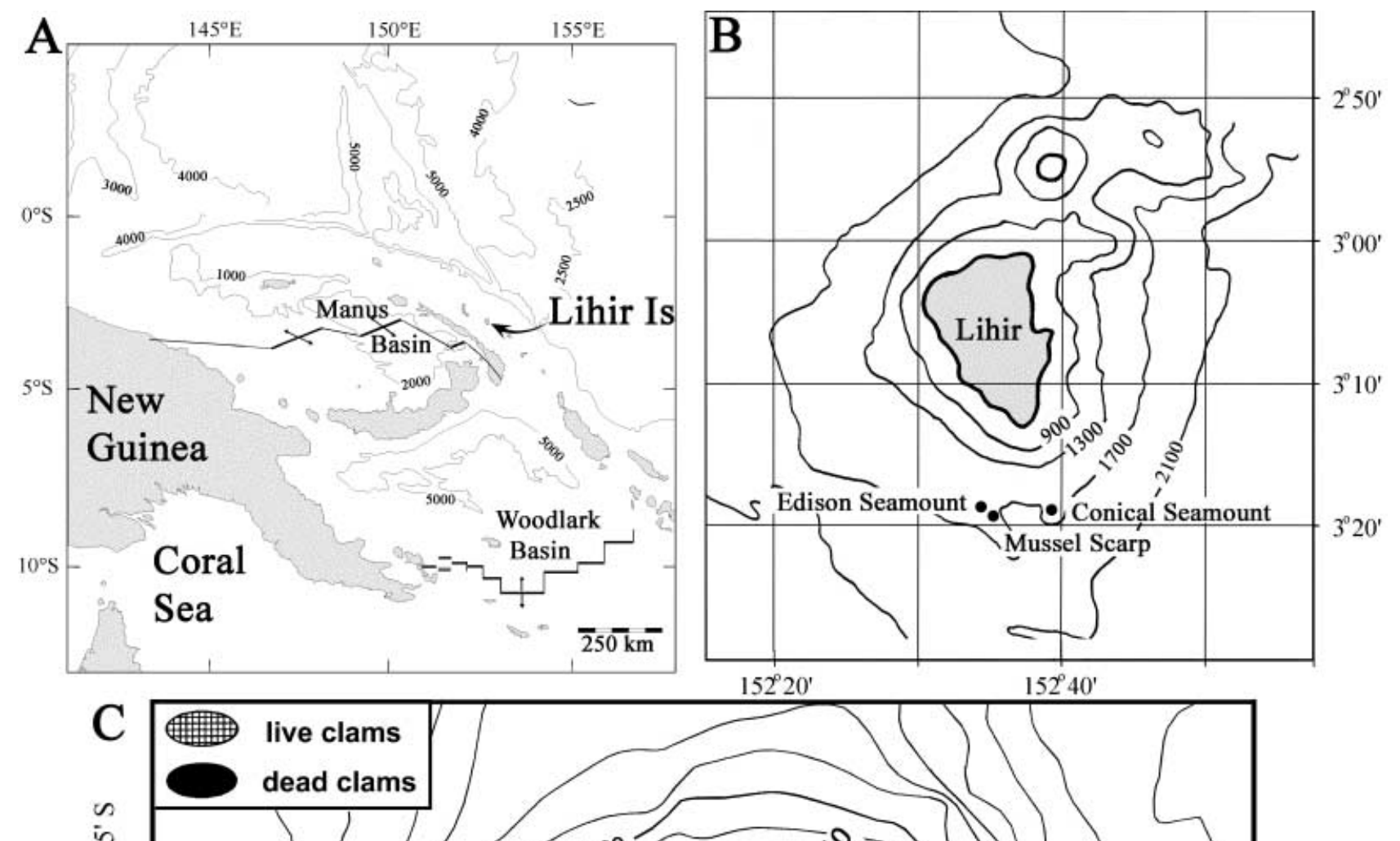

\section{EDISON Seamount}

Figure 1. (A) Lihir Island, located in the Feni-Tabar island arc; (B) Edison seamount is a volcanic cone on the southern slope of the island; (C) positions of the stations where large samples of Leucolepas longa were collected: GTVA 29 and 66 in 1994 , the other three in 1998. (Bathymetric detail based on Herzig \& Hannington, 1995). 
Table 1. Stations where collections of Leucolepas longa were made on Edison Seamount. Samples were retrieved by a video camera guided grab (=GTVA) or a dredge $(=D R)$.

\begin{tabular}{|c|c|c|c|c|}
\hline Station & Date & Co-ordinates & Depth $(\mathrm{m})$ & Comments \\
\hline GTVA 29 & $20 / 3 / 94$ & $3^{\circ} 18.9^{\prime} \mathrm{S} 152^{\circ} 34.9^{\prime} \mathrm{E}$ & 1483 & selected individuals of several new species retained \\
\hline GTVA 66 & $29 / 3 / 94$ & $3^{\circ} 19.1^{\prime} \mathrm{S} 152^{\circ} 34.9^{\prime} \mathrm{E}$ & 1492 & selected individuals of several new species retained \\
\hline GTVA $10 * *$ & $23 / 7 / 98$ & $3^{\circ} 18.9^{\prime} \mathrm{S} 152^{\circ} 34.9^{\prime} \mathrm{E}$ & 1440 & dead clam shells and barnacles \\
\hline GTVA $11 * *$ & $23 / 7 / 98$ & $3^{\circ} 19.1^{\prime} \mathrm{S} 152^{\circ} 34.9^{\prime} \mathrm{E}$ & 1445 & $900 \mathrm{~kg}$ of sulphide-rich mud; live clams and barnacles \\
\hline $31 \mathrm{DR}$ & $25 / 7 / 98$ & $\begin{array}{l}3^{\circ} 19.5^{\prime} \mathrm{S} 152^{\circ} 35.4^{\prime} \mathrm{E} \text { to } \\
3^{\circ} 19.1^{\prime} \mathrm{S} 152^{\circ} 35.8^{\prime} \mathrm{E}\end{array}$ & $\begin{array}{c}1630 \text { to } \\
1506\end{array}$ & $\begin{array}{l}\text { a few clam shells, with Fe-sulphide coatings; selected } \\
\text { barnacles }\end{array}$ \\
\hline GTVA $33 * *$ & $25 / 7 / 98$ & $3^{\circ} 19.1^{\prime} \mathrm{S} 152^{\circ} 34.9^{\prime} \mathrm{E}$ & 1446 & $\begin{array}{l}200 \mathrm{~kg} \text { of large clams in a muddy matrix with many } \\
\text { barnacles }\end{array}$ \\
\hline 44 GTVA ‘Mussel Scarp’ & $26 / 7 / 98$ & $3^{\circ} 19.4^{\prime} \mathrm{S} 152^{\circ} 35.4^{\prime} \mathrm{E}$ & 1598 & $\begin{array}{l}50 \mathrm{~kg} \text { of foraminiferal ooze, mussel clump with carbonate } \\
\text { blocks }\end{array}$ \\
\hline 45 GTVA 'Mussel Scarp’ & $26 / 7 / 98$ & $3^{\circ} 19.4^{\prime} \mathrm{S} 152^{\circ} 35.4^{\prime} \mathrm{E}$ & 1606 & mud with a few clams, vestimentiferans and barnacles \\
\hline
\end{tabular}

**, indicates the large samples on which observations of size and reproductive activity were made. The types for the species description were selected from GTVA 33.

present on Lihir where hydrothermal precipitation of gold is actively forming the Ladolam deposit; epithermal gold deposits are located on Conical Seamount about $2 \mathrm{~km}$ from Edison (Herzig \& Hannington, 1995). Sea-floor fluid flows on Edison Seamount have not been characterized; thus, whether this setting is 'hydrothermal' or 'cold seep' is not yet clear. Herzig \& Hannington (1995) report a high methane anomaly in the water near Edison Seamount. Comparison might be made with the lowtemperature hydrothermalism reported from sites in the Woodlark Basin and the Manus Basin (Bogdanov et al., 1997; Galkin, 1997) and the issuing fluids at Edison are probably cooler than those at mid-ocean ridges. Eolepad barnacles are previously known only from areas of vigorous hydrothermal venting (Newman, 1979; Jones, 1993; Buckeridge, 2000).

\section{Collection}

The site was sampled during two expeditions of 'Sonne': SO-94 in March 1994 and SO-133 in June 1998 (Herzig \& Hannington, 1994, 1998). The expeditions were designed to map the island arc and to investigate the potential for sea-floor gold deposition; documentation of the fauna was an added objective of the later cruise. Leucolepas longa is currently known only from sample sites within $1.5 \mathrm{~km}$ of each other on Edison Seamount (Table 1; Figure 1). Extensive exploration of the region was not possible, but four other seamounts around Lihir Island yielded no more specimens. The summit of Edison, a sedimented plateau, was a major sampling target after extensive beds of large vesicomyid clams were discovered there.

A TV-controlled grab (GTVA) allowed precise sampling under visual guidance. The large 3.2 tonne grab can extract up to $2 \mathrm{~m}^{2}$ surface area, thereby retrieving large volumes of sediment or rock. Much better visual resolution of the sea-floor was achieved with a camera sled (OFOS) towed over long distances. A realtime video signal guides sled height while a PHOTOSEA 5000 still camera retrieves $35 \mathrm{~mm}$ photographs upon operator command. This camera can be focused to a minimum distance of $0.6 \mathrm{~m}$ and is equipped with two laser beams that imprint a $15 \mathrm{~cm}$ scale on the images. Upon retrieval of the first specimens in 1994, it was not possible to preserve large numbers, but sub-samples (courtesy I.R. Jonasson of the Canadian Geological Survey) were preserved in overproof vodka and methanol. Preservation was good enough to determine a high level of reproductive activity involving release of large lecithotrophic nauplius larvae. In 1998, barnacles in good condition were selected from the grabs and maintained alive (at $4^{\circ} \mathrm{C}$ ) for several days while size measurements (stalk and capitulum length) of unfixed specimens were taken. They were then preserved in either $5 \%$ seawater-formalin or $75 \%$ ethanol. Specimens from the 1994 cruise were perforce measured after fixation, but the peduncle, which is lightly armoured with small scales, does not contract.

Several individuals from GTVA 10, 11 and 33 released nauplii over the course of four days. Active larvae from each group were pipetted into Petri dishes to begin cultures at $4^{\circ} \mathrm{C}$. The water was partially replaced each day. Subsamples of the larvae from Station 10 were taken every 3 to 5 days and fixed in Trump's solution $(2 \%$ glutaraldehyde, $2 \%$ paraformaldehyde in $0.05 \mathrm{M}$ cacodyl buffer, pH 7.4); other cultures were subsampled less frequently. Fixed larvae were assessed for stages of development with a stereomicrosope and lengths measured with an eyepiece graticule. Selected larvae were dehydrated via ethanol, subjected to critical point drying, mounted on stubs, coated with gold and examined by scanning electron microscopy (SEM) in an Hitachi S3500N. Recently settled stages found in the preserved samples were also examined by scanning electron microscopy. Later stage juveniles are illustrated in Southward \& Jones (2002). Preserved barnacles were dissected to assess reproductive condition.

\section{RESULTS \\ Habitat}

Leucolepas longa appears to occur only with other species that are indicative of dissolved sulphide fluxes. Highest abundances are on the summit of Edison, attached to the 

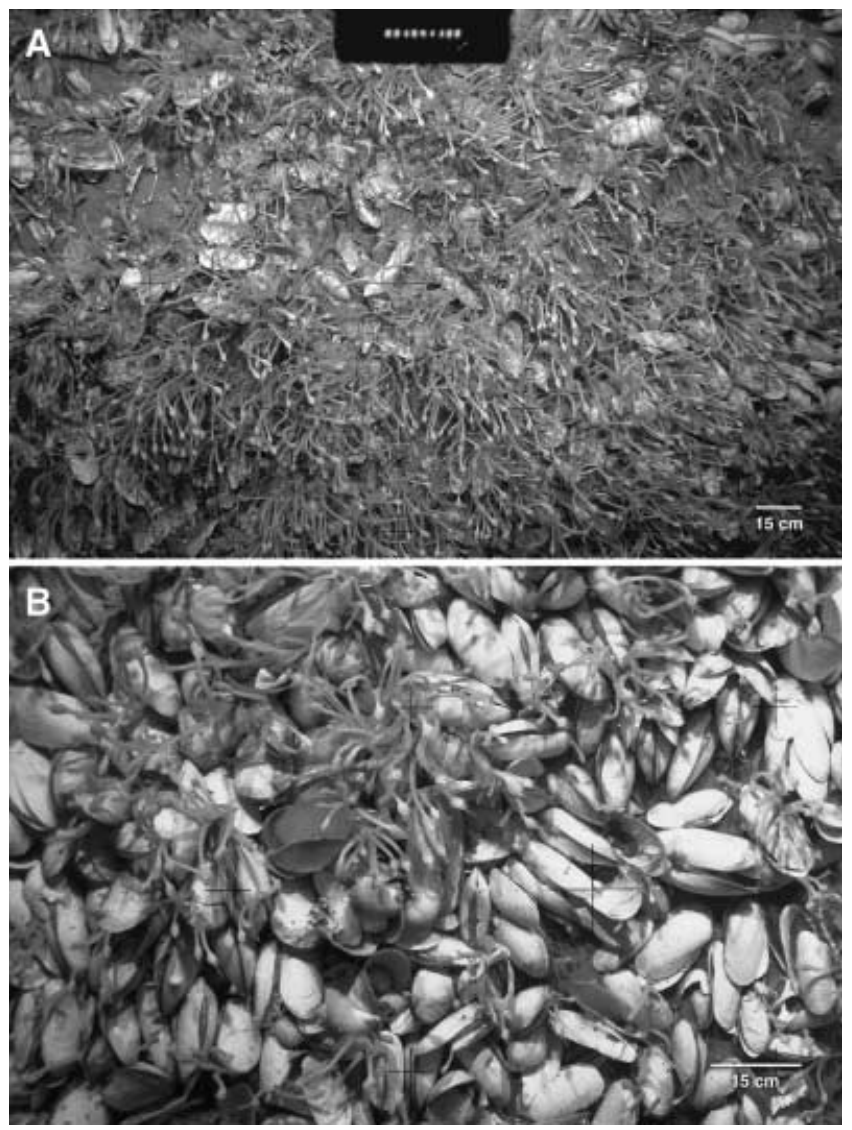

Figure 2. Photographs taken from a camera sled ('OFOS') of barnacle masses on Edison Seamount. The $15 \mathrm{~cm}$ scale in both images applies to the central portion of the photo where two red laser spots are present in original colour images. (A) Camera has swung slightly over a relatively flat, sedimented bottom. Hundreds of barnacles are attached to clam shells protruding from the sediment: 1030 barnacles were counted in the central $2.3 \mathrm{~m}^{2}$ of this image; (B) a closer view, showing cirri extended from many individuals of Leucolepas longa. The barnacles are clumped, as they tend to settle on each other. Most vesicomyids in this image are empty shells but some live individuals are present.

partially buried clams (Figure 2A). These vesicomyids, which harbour sulphide-oxidizing symbiotic microbes in their gills, form the greatest biomass of the fauna at Edison Seamount; they are concentrated in two 'fields', north and south, over $100 \mathrm{~m}$ wide (Stecher \& Tunnicliffe, unpublished observation). Here, other organisms present include alvinocarid shrimps, galatheid crabs, maldanid polychaetes, limpets, including Bathyacmaea jonassoni (Beck, 1996) and large turrid snails, Phymorhynchus wareni (Sysoev \& Kantor, 1995). Mussel Scarp (Figure 1) is also colonized by two undescribed species of mytilids and a novel vestimentiferan tube-worm, Paraescarpia echinospica (Southward et al., 2002).

The barnacle requires hard substrata for initial settlement and colonizes available rocks, concretions, shells and other animals. It is most often found associated with vesicomyid and mytilid bivalves. Live bivalve distribution is strongly localized; however, photographic transects show extensive areas of dead clams, and the barnacles can extend beyond the live clam beds into these shell areas, though not by more than a few tens of metres. In areas where there are large numbers of live clams, barnacles tend to occur mostly on dead shells and on rocks, where they show greatest elongation of the peduncles. The barnacle density is sometimes high enough to obscure the underlying clams. As the vesicomyids are capable of burrowing and shifting, the barnacle's hold may sometimes be precarious. Most often, attachment occurs on the posterior portion of the shell of the live clam that protrudes from the sediment and where abrasion by neighbouring clams is limited. The barnacles form dense clumps by settling upon one another, and this makes it difficult to estimate total numbers. Estimates of density from still photographs are minima because of clumping and poor resolution of individuals under $5 \mathrm{~mm}$ long. Three frames occupying areas of 2, 2.3 and 1.2 square metres yielded densities of 224, 440 and 1032 barnacles $\mathrm{m}^{-2}$ (Figure 2B).

Leucolepas was also found attached to the tubes of the vestimentiferan, Paraescarpia echinospica (Southward et al., 2002) that lives with the posterior part of the tube in sediment. Densities are lower here (up to $18 \mathrm{~m}^{-2}$ ) reflected by the low density of the tubeworms. Note that eolepad barnacles also attach to vestimentiferan tubes at venting sites in the Lau Basin (Southward \& Newman, 1998). Juvenile Leucolepas occur frequently on conspecific adult barnacles, including occasionally on the plates of the capitulum as well as the stalks. This behaviour results in bushes or dense clumps of barnacles originating from a single 'stem' individual supporting up to 30 other individuals, some of which may grow larger than the primary settler.

\section{Population characters}

The two preserved samples taken in March 1994 were assessed for size characteristics, as illustrated in Figure 3. Both 1994 samples had shorter peduncles than the 1998 specimens. Elongation of the peduncle apparently ceased in these individuals after they reached about $110 \mathrm{~mm}$. The capitulum is rarely larger than $25 \mathrm{~mm}$ long, a size that does not appear to depend on peduncle length. Total lengths of a random subsample of the 1998 specimens, shown in Figure 4, ranged from $2 \mathrm{~mm}$ to $330 \mathrm{~mm}$. However, selected specimens from Station 33 included one with a total length of $404 \mathrm{~mm}$ (Table 2). The sample
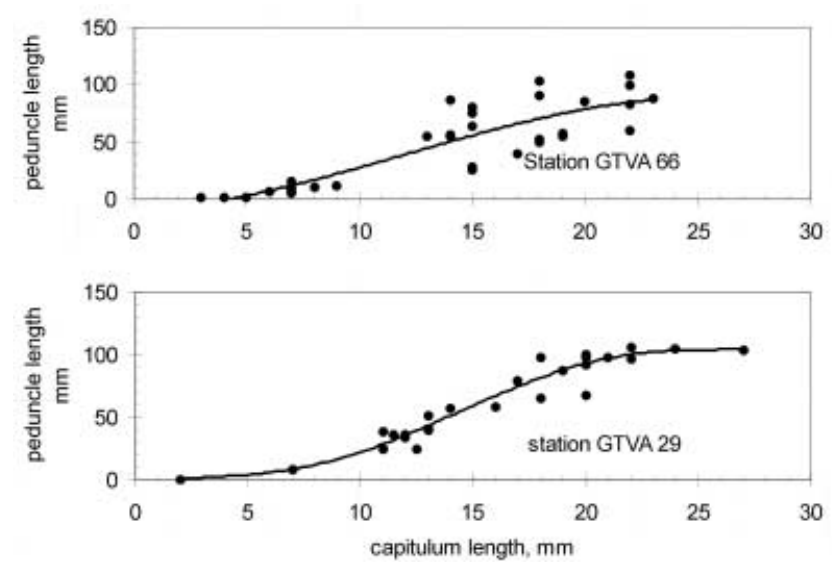

Figure 3. Peduncle vs capitulum lengths of specimens of Leucolepas longa specimens selected from the two samples taken in 1994. The trend lines are polynomial fits. 
Table 2. Dimensions of selected clump of elongated specimens of Leucolepas longa from GTVA 33.

\begin{tabular}{lccc}
\hline & $\begin{array}{c}\text { Capitulum } \\
\text { length }\end{array}$ & $\begin{array}{c}\text { Peduncle } \\
\text { length }\end{array}$ & $\begin{array}{c}\text { Total } \\
\text { length }\end{array}$ \\
\hline Primary settler 1 & 25 & 379 & 404 \\
Attached to 1 & 26 & 255 & 281 \\
Attached to 1 & 23 & 127 & 150 \\
Attached to 1 & 22 & 204 & 226 \\
Primary settler 2 & 28 & 359 & 387 \\
Mean & 24.8 & 264.8 & 289.6 \\
SD & 2.39 & 105.71 & 107.45 \\
\hline
\end{tabular}

GTVA, video camera guided grab.

from Station 10 had notably shorter peduncles, to a maximum of $200 \mathrm{~mm}$ (mean $98 \mathrm{~mm}$ for those individuals with a capitulum length over $11 \mathrm{~mm}$ ). However, capitulum size was not significantly smaller than in the Station 11 and 33 samples. The small sample from Station DR 31 had short peduncles (mean length $68.4 \mathrm{~mm}$ ) and capitula (mean length $14.2 \mathrm{~mm}$ ) and maximum total length was only $134 \mathrm{~mm}$, but the specimens were selected from many damaged individuals and may not be representative of the population. Mean lengths of all specimens and selected mature individuals from the three large samples are given in Table 3. The two samples from the south Edison field differed significantly in peduncle length of adult barnacles ( $t$-test $P<0.01)$. The mean peduncle length of individuals over $11 \mathrm{~mm}$ capitulum length was $142 \mathrm{~mm}$ at Station 11 and $188 \mathrm{~mm}$ at Station 33. There was a corresponding significant difference in capitulum lengths of the mature specimens (analysis of variance $P<0.01$ ), with those at Station 11 breeding at a smaller size.

Recently settled individuals were rare, only 18 out of 275 were less than $4 \mathrm{~mm}$ long. There was only a single specimen, presumed recently settled, less than $1 \mathrm{~mm}$ total length (Figure 5).

Of 275 specimens examined in 1998, only one was found dead. There were few attachment scars present to indicate recent losses. There was no interpretable evidence of predation on the barnacle clumps, although the turrid gastropod could be a local predator. In the 1994 collections, egg incubation was seen only in specimens over $17 \mathrm{~mm}$ capitulum length where $50 \%$ of the dissected
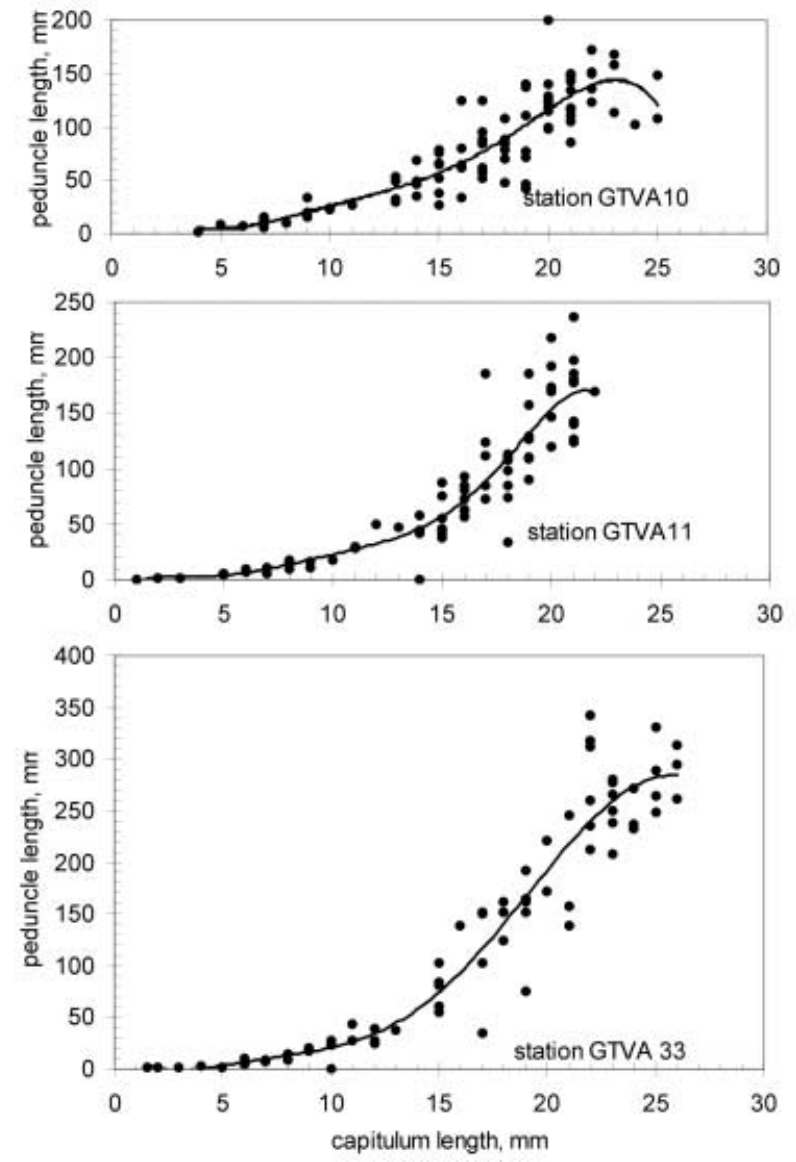

Figure 4. Peduncle vs capitulum lengths of Leucolepas longa specimens from the 1998 Stations 10, 11, and 33. The trend lines are polynomial fits.

specimens fostered egg masses. For the 1998 collections, embryos were present in $75 \%$ of the population over $12 \mathrm{~mm}$ capitulum length.

\section{Feeding and behaviour}

From examination of the mouth parts, Leucolepas longa appears to be adapted to feed on small particles such as, for example, sulphur bacteria (Southward et al., 2002), as

Table 3. Leucolepas longa. Mean lengths and standard deviations of capitula and peduncles in three large samples of 1998. Grouped as all specimens and selected mature specimens.

\begin{tabular}{|c|c|c|c|c|c|c|}
\hline & \multicolumn{2}{|c|}{ GTVA 10} & \multicolumn{2}{|c|}{ GTVA 11} & \multicolumn{2}{|c|}{ GTVA 33} \\
\hline & Capitulum & Peduncle & Capitulum & Peduncle & Capitulum & Peduncle \\
\hline \multicolumn{7}{|c|}{ All specimens } \\
\hline Mean & 16.48 & 81.39 & 16.58 & 113.20 & 15.43 & 129.08 \\
\hline SD & 5.26 & 49.44 & 6.44 & 81.93 & 7.53 & 111.43 \\
\hline $\mathrm{N}$ & 92 & & 101 & & 74 & \\
\hline \multicolumn{7}{|c|}{ Mature specimens } \\
\hline Mean & 20.17 & 117.87 & 17.20 & 109.98 & 18.84 & 185.32 \\
\hline $\mathrm{SD}$ & 2.06 & 33.42 & 3.23 & 54.04 & 4.98 & 92.40 \\
\hline $\mathrm{N}$ & 58 & & 63 & & 58 & \\
\hline
\end{tabular}

GTVA, video camera guided grab. 


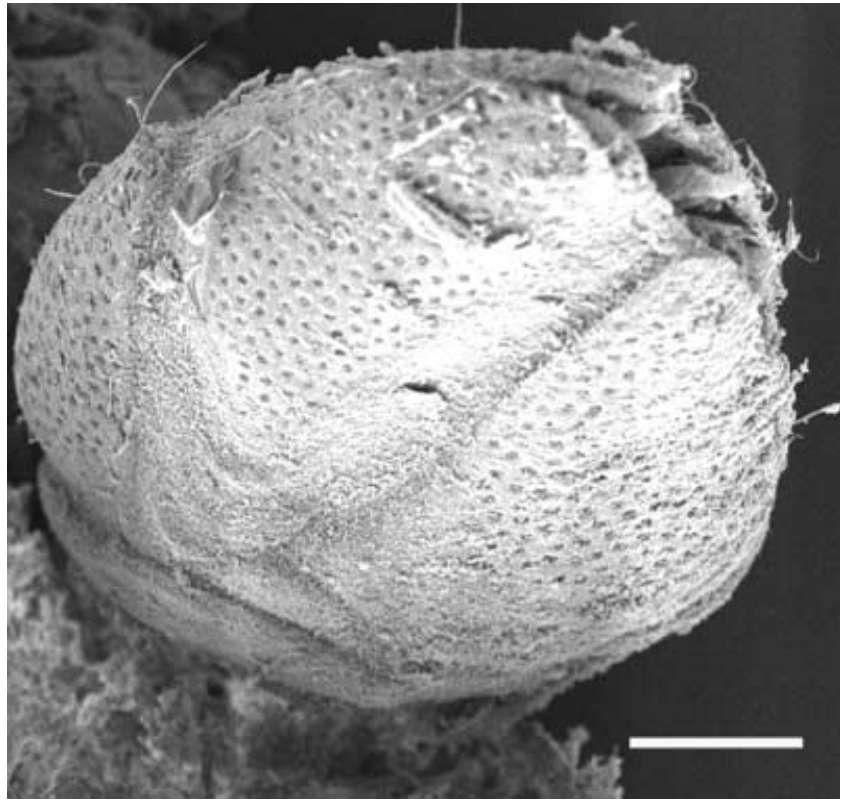

Figure 5. First metamorph stage of Leucolepas longa showing primordial shell sculpturing. Photograph by C.L. Singla. Scale bar: $100 \mu \mathrm{m}$.

appears to be the case in other neolepadines (Southward \& Newman, 1998). Examination of the cirri under high power light microscopy showed traces of filamentous bacteria on cirri I and II, but not in the abundances seen in the 'bacterial gardens' on the cirri of a neolepadine barnacle from Lau (Southward \& Newman, 1998). There was no evidence for any internal accumulation of bacteria.

Food pellets, encased in very thin peritrophic membranes, were extracted and examined by light microscopy. Amorphous mineral particles made up the bulk of the pellets. There were a few diatom frustules and small rounded objects of about $10 \mu \mathrm{m}$ containing sulphur particles, but no trace of animal remains. There is a prominent first tooth on the mandible that would assist mastication of larger prey if such was available, but the rest of the mandible shows comb-like structures that appear efficient in retaining fine particles (Southward \& Jones, 2002).

The cirri can extend 20 to $30 \mathrm{~mm}$ outside the capitulum and are held in a cupped-fan position as seen in images and sometimes maintained in fixed material (Figure 6). Specimens kept in seawater on the ship rarely retracted the cirri, which remained extended for minutes at a time; close sea-floor photographs reveal most individuals with extended cirri. The capitulum can move vigorously around the stalk, but unlike many of the pelagic lepads the peduncle is not retractable and movement is thus confined. However, the peduncle scales are smaller than in Neolepas species from mid-ocean vents (Southward \& Jones, 2002), allowing some degree of flexibility. Video sequences taken during recovery of collected specimens within the TV-guided grab show the stalks sweeping with the cirral net extended.

A selected clump of elongated specimens (Table 2) attached to a piece of vesicomyid shell included two primary settlers and three others attached to one of the primary settlers. The secondary specimens had shorter

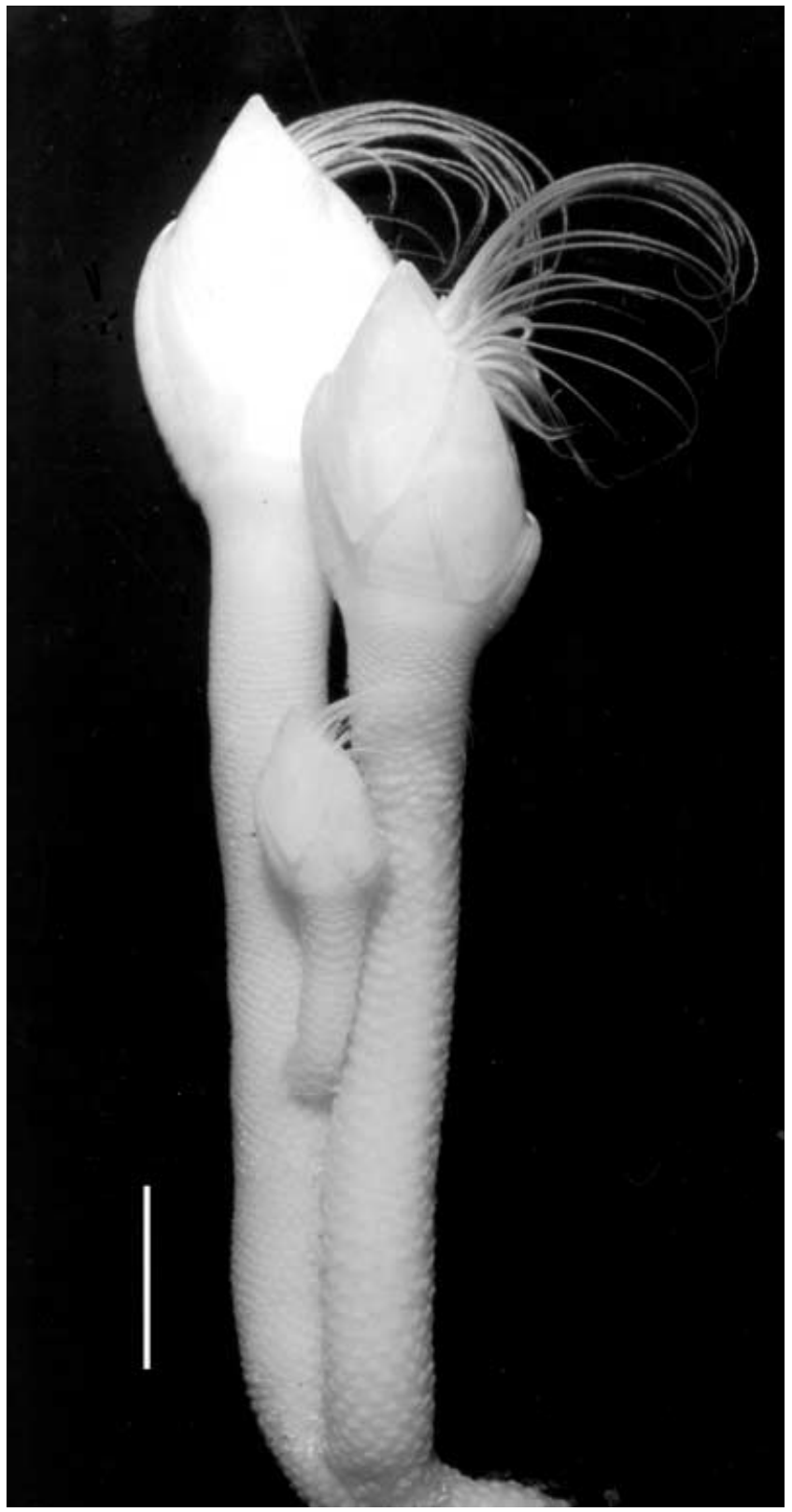

Figure 6. Group of Leucolepas longa with cirral net still expanded in preserved condition. Scale bar: $10 \mathrm{~mm}$.

Table 4. Distribution of reproductive stages in Leucolepas longa at the three major collection sites.

\begin{tabular}{lccc}
\hline Station & GTVA 10 & GTVA 11 & GTVA 33 \\
\hline Number examined & 97 & 103 & 75 \\
$\quad$ gonad stage: & 40 & 32 & 33 \\
$\quad$ not breeding & 32 & 8 & 4 \\
$\quad$ oocytes developing & 13 & 15 & 3 \\
$\quad$ ripe ovary & & & \\
In mantle cavity: & 4 & 38 & 30 \\
$\quad$ egg masses & 1 & 3 & 4 \\
$\quad$ embryos ready to hatch & & 5 & 1 \\
$\quad$ free nauplii & 12.4 & 44.7 & 46.7 \\
& & & \\
$\quad$ of sample incubating eggs & & & \\
$\quad$ or nauplii & &
\end{tabular}

GTVA, video camera guided grab. 

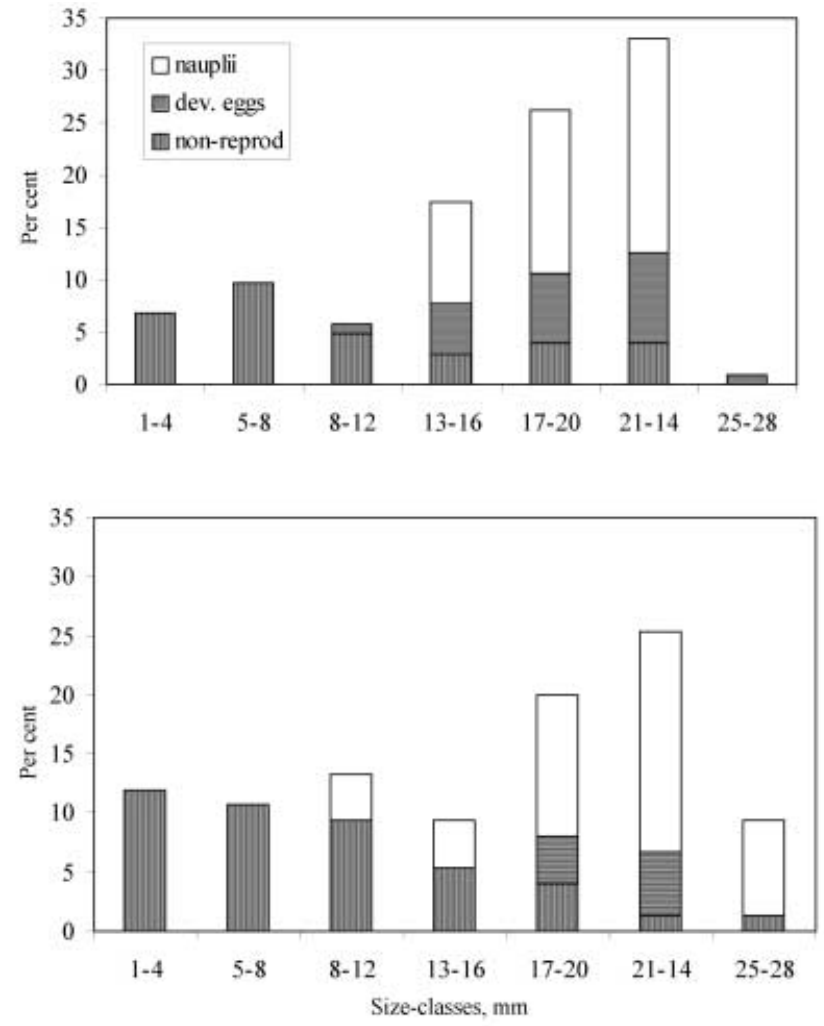

Figure 7. Leucolepas longa. Percentage of animals of different size-classes incubating eggs, embryos or hatched nauplii, 1998 stations.

peduncles, and appeared to have grown upwards to the level of the capitula of the primary settlers so that all five cirral nets were within a radius of $80 \mathrm{~mm}$.

\section{Reproduction}

Another eolepad that has been studied (Jones, 1993) is a fully functioning hermaphrodite, and the Edison Seamount species is similar. However, copulation was not seen in live specimens maintained on the ship, and the penis was always held folded over, with its tip between the bases of the first cirri, fairly close to the entrances to the oviducts. This was also the appearance in preserved material.

The paired ovaries are situated in the top of the stalk, just below the capitulum. Individuals as small as $12 \mathrm{~mm}$ capitulum length had egg masses within the mantle cavity, although at this size, egg numbers were generally low (below 50, compared to $100 \mathrm{~s}$ in the larger animals).

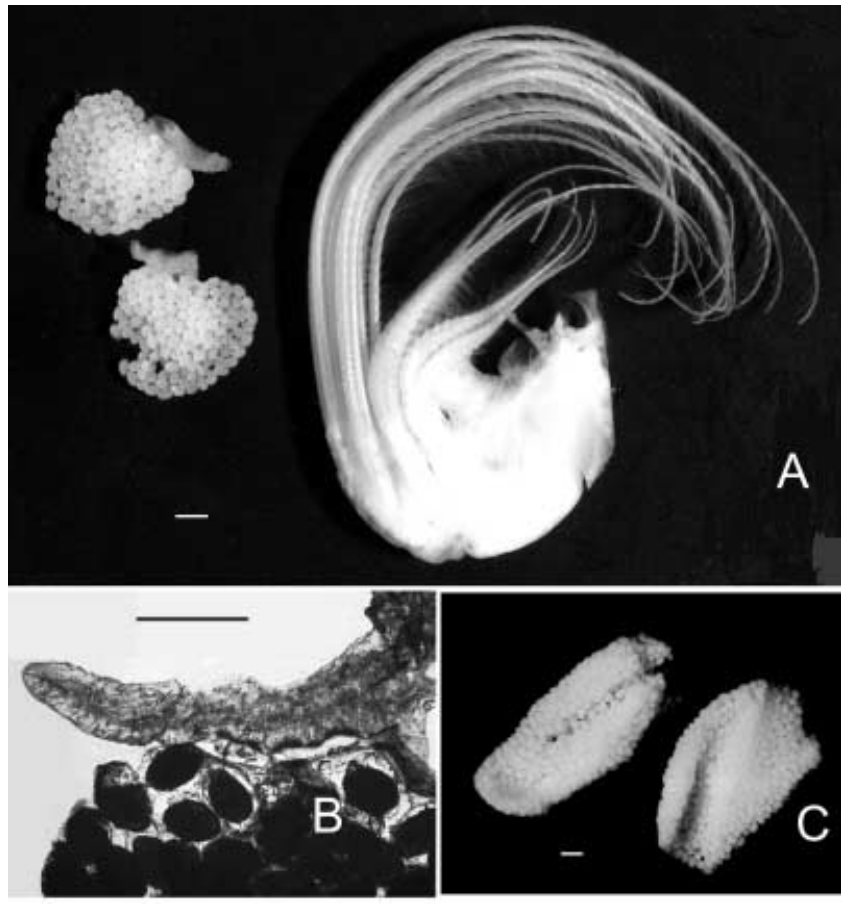

Figure 8. Leucolepas longa. (A) Paired egg masses attached to ovigerous frenae, after being detached from the mantle cavity lining, shown alongside the 'body' of the barnacle (prosoma and thorax). Specimen from Station 31, capitulum length $15 \mathrm{~mm}$; (B) closer view of a frenum and eggs by transmitted light after clearing in polyvinyl lactophenol; (C) larger egg masses with more elongated shape than in A, from a big specimen taken at Station 33, capitulum length $25 \mathrm{~mm}$. Scale bars: $1 \mathrm{~mm}$.

Of the barnacles in the Station 10 sample, only $12 \%$ had egg masses or larvae in the capitulum, and then only in animals with capitula $17 \mathrm{~mm}$ in length or more. At Stations 11 and $33,45 \%$ and $47 \%$, respectively, were breeding including one of $12 \mathrm{~mm}$ capitulum length that contained small egg masses in the capitular cavity (Table 4, Figure 7). Some animals that were brooding larvae also had well-developed eggs in the ovaries.

The egg masses are attached to typical lepadomorph type ovigerous frenae (Walker, 1978; Jones, 1993) in the lower part of the capitular cavity at the level of the median latus (Figure 8). In preserved specimens examined, the egg masses vary considerably in size, shape and colour, from as few as 20 yellowish-white eggs in rounded masses in small individuals, to several hundred deep yellow eggs in bilobed masses in larger individuals.

Table 5. Mean lengths $(\mu \mathrm{m})$ and standard deviations of the cultured larval stages of Leucolepas longa. Furca length of Stage I was not measured.

\begin{tabular}{|c|c|c|c|c|c|c|c|}
\hline & \multicolumn{3}{|c|}{ Carapace } & \multirow{2}{*}{$\begin{array}{l}\text { Furca } \\
\text { length }\end{array}$} & \multirow[b]{2}{*}{ SD } & \multirow{2}{*}{$\begin{array}{l}\text { Total } \\
\text { length }\end{array}$} & \multirow[b]{2}{*}{ SD } \\
\hline & $\mathrm{N}$ & Length & SD & & & & \\
\hline Stage I & 33 & 480.96 & 21.88 & - & - & 693.91 & 43.87 \\
\hline Stage II & 18 & 483.55 & 26.79 & 629.78 & 40.78 & 749.70 & 49.98 \\
\hline Stage III & 8 & 501.64 & 19.94 & 630.26 & 25.39 & 924.26 & 16.55 \\
\hline Stage IV & 2 & 521.85 & 31.18 & 668.85 & 31.18 & 999.60 & 0 \\
\hline
\end{tabular}



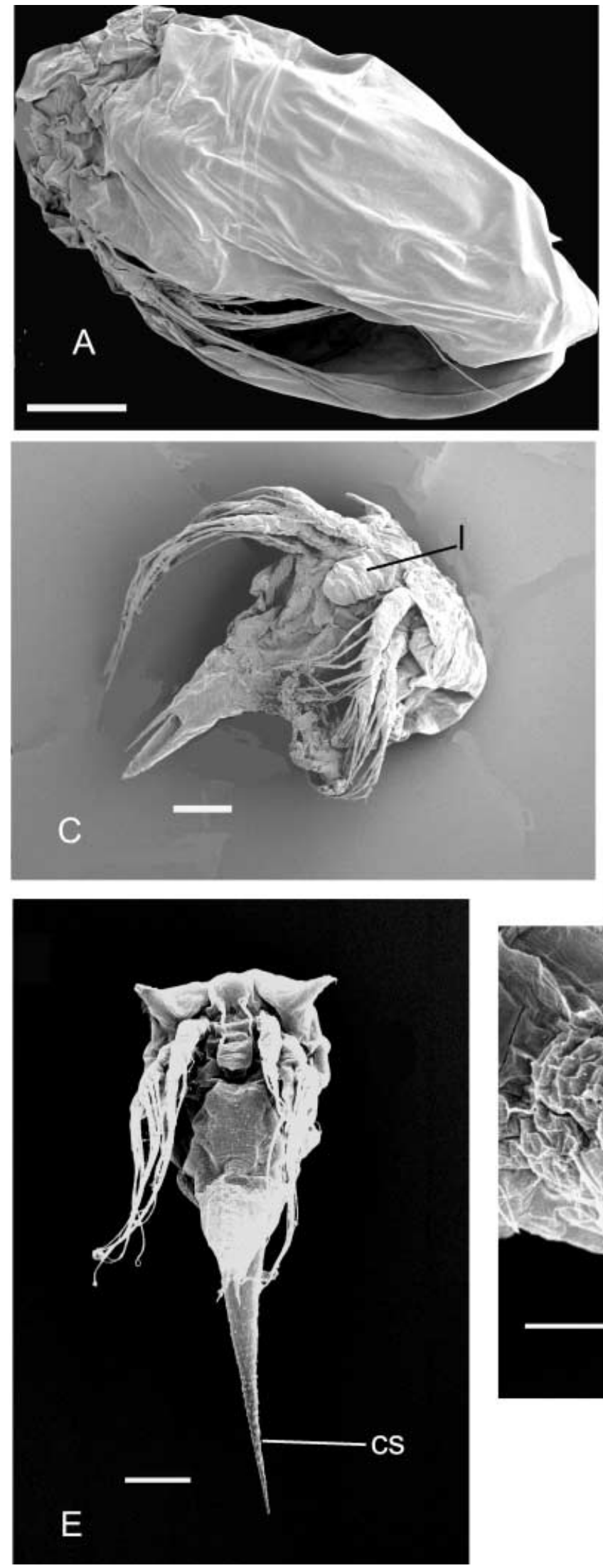
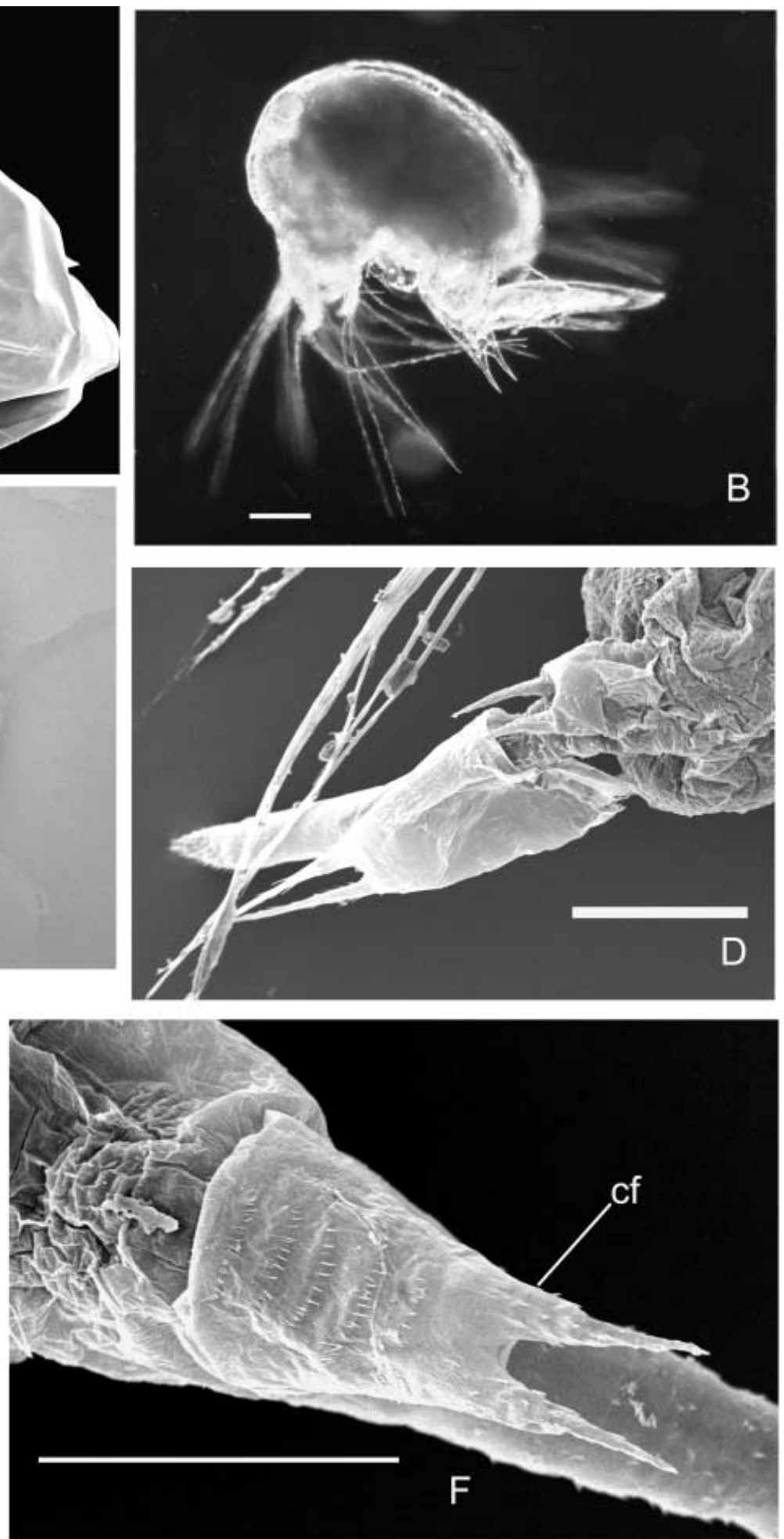

Figure 9. Stages I and II nauplii of Leucolepas longa. (A) Scanning electron microscopy (SEM) of hatching egg; (B) recently hatched Stage I, caudal spine bent, latero-frontal horns not erect; (C) SEM ventral view of Stage I showing labrum (l) and short caudal spine; (D) SEM of caudal region showing exuvium from Stage I attached to emerging caudal process of Stage II; (E) ventral SEM of Stage II showing elongated caudal spine (CS); (F) SEM of caudal furca (cf) of Stage II with signs of segmentation. Scale bars: $100 \mu \mathrm{m}$. 

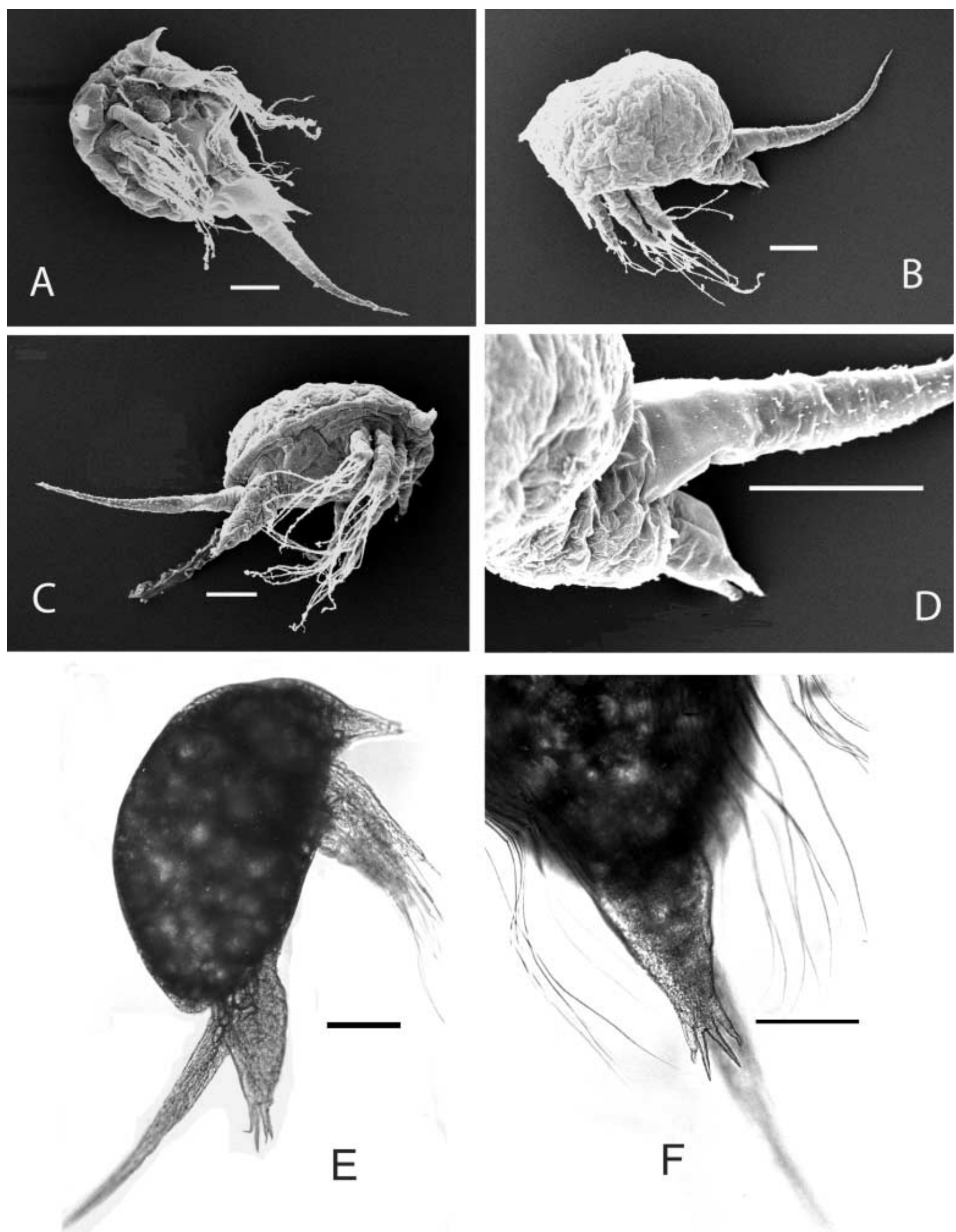

Figure 10. Stages II to IV of nauplii of Leucolepas longa. (A) Scanning electron microscopy (SEM) of Stage II; (B) SEM of Stage III; (C) SEM of transition Stage III to IV; (D) SEM showing caudal process, Stage III; (E) side view of Stage IV; (F) closer view of Stage IV showing four caudal spines. Scale bars: $100 \mu \mathrm{m}$.

However, the larger masses do not extend up the sides of the mantle space to the top of the capitulum, as in some lepadomorphs. Approximately 870 eggs were counted in an individual with a capitulum length of $21 \mathrm{~mm} ; 612$ nauplii and a few unhatched eggs were present in a specimen with a capitulum length of $24 \mathrm{~mm}$. Preserved egg capsules from the mantle cavity, containing developing nauplii, had a mean length of $636.1 \pm 42.56 \mu \mathrm{m}$. Preserved early nauplii had a mean total length of $697 \pm 34.32 \mu \mathrm{m}$. 


\section{Larval behaviour}

Of the 275 adults examined live, seven had free nauplii in the capitulum. This low frequency, and the abundance of larvae found swimming in the buckets $12 \mathrm{~h}$ after collection, suggest that free nauplii are not brooded for very long after hatching. The hundreds of free-swimming nauplii released came from five or six individuals that retained some nauplii inside the capitular cavity, not releasing all simultaneously. At $18 \mathrm{~h}$, the buoyant larvae were active but moving very weakly at the surface floating ventral side up. The limbs beat in short bursts of $1-2 \mathrm{~s}$ to move about $5 \mathrm{~mm}$ before pausing a long time. No reaction to light was evident during any period the larvae were observed. At $48 \mathrm{~h}$, limb movements had increased to $10-30 \mathrm{~s}$ bursts. By three days, sustained swimming brought the nauplii to the bottom of the dish where they swam dorsal side up. Short bursts of swimming were followed by periods of quiescence, during which there were complex movements of the appendages. At five days, moults were found in the dish, and longer larvae, presumed to be Stage II, could be seen. From six to ten days, swimming was very active in bursts of up to minutes at a time. The larvae now appeared less buoyant and did not float upward when resting. Mortality up to ten days appeared to be low.

Microscopic examination of preserved subsamples showed that some larvae had undergone metamorphosis in the first $24 \mathrm{~h}$ after release. Other larvae remained in Stage I for several days. Subsamples of the cultures from Stations 10 and 33 showed $40 \%$ Stage I at $3 \mathrm{~d}, 15 \%$ at $6 \mathrm{~d}$ and none at $7 \mathrm{~d}$; while the culture from Station 11 still contained $16 \%$ Stage I after $10 \mathrm{~d}$. No Stage I larvae remained in the cultures after $13 \mathrm{~d}$, when all living specimens appeared to belong to Stage II. No further change was seen until $24 \mathrm{~d}$ when a single Stage III was found. A few more Stage III larvae were present in the subsample taken at $42 \mathrm{~d}(43 \%)$. The culture experiments had to be discontinued after $45 \mathrm{~d}$, and the final fixed sample of active larvae contained four at Stage II; four at Stage III and two at Stage IV. These active larvae still had much lipid reserve, so that there could have been longer survival. There were also several moribund larvae of indeterminate stage, and it seems probable that some larvae failed to metamorphose from Stage II.

\section{Larval stages}

The preserved samples showed small changes in carapace length and furca length between stages (Table 5), but the best indicator of growth was total length. We have used this measurement, combined with features of the caudal furca, to allocate the growing larvae to tentative stages. The accuracy of total length depends on the caudal spine remaining undamaged.

The most marked change was the metamorphosis from Stage I to Stage II. The first stage has a short and thick caudal spine, almost the same length as the long caudal furca (Figure 9B-D), and the latero-frontal horns are curved back close to the cephalic shield. The labrum is relatively unspecialized and remains so through the following stages (Figures 9C,E \& 10A). There are no gnathobases on the naupliar appendages. Some larvae may have had difficulty casting from Stage I, and Figure 9D shows a Stage II larva still carrying part of the cast exuvium from Stage I. The major developments seen at Stage II are: an increase in length of the caudal spine which appears thinner than in Stage I; a change in the shape of the furca; appearance of segmentation in the abdomen; and greater prominence of the latero-frontal horns (Figures 9E,F \& 10A). Changes in Stage III are less obvious, but abdominal segmentation is more marked (Figure 10B,D). Two larvae in the cultures reached Stage IV, just under $1 \mathrm{~mm}$ long, with four spines on the caudal process (Figure 10C,E,F). The caudal spine was still very long and there were no signs of the carapace spines that usually develop in late stage nauplii. The smallest settled stage found in the preserved samples $(\sim 0.5 \times 0.5 \mathrm{~mm})$ is shown in Figure 5.

\section{DISCUSSION}

Both the high densities and the restriction of Leucolepas longa to substrata associated with sulphide seepage indicate that this species is adapted to, and perhaps restricted to, sulphide-rich habitats. Although two specimens of another lepad species were collected, no sessile barnacles were found. The distribution of the barnacle is determined by apparent sulphide seepage and suitable substratum. The presence of a large methane anomaly at Mussel Scarp and the abundance of vesicomyid clams has been regarded as evidence of dissolved sulphide presence, through microbial conversion of the sediment methane (Stecher \& Tunnicliffe, personal observations).

Collections in 1998 on the southern seamount rim indicate higher sulphide fluxes. Stations 11 and 33 featured large clams while at Station 34 clams were all smaller sizes suggestive of recent recruitment on top of a large shell hash. Relatively few barnacles were present at this latter site. The 1994 sample GTVA 29 was taken in the same northern rim field as Station 10: these samples have peduncles about half the length of the southern rim collections although capitulum size does not differ. Collections at Station 10 (1998) included large numbers of dissolving clam shells and it seems sulphide seepage was too low to sustain live clams. The barnacles at GTVA 10 were associated with dead clam shells and appeared to be located on the periphery of venting fluids, hence the site may represent sub-optimal growing conditions.

The peduncles of Leucolepas longa grow much longer than those of other eolepad barnacles. Peduncle length probably reflects optimal distance above bottom for suspension feeding, and longer peduncles might indicate either a stronger vertical flux or a stronger lateral resuspending current. Crowding may also induce elongation of the peduncle, as happens with dense settlements of sessile barnacles where the shells become 'columnar'. A long peduncle might also give the animals a much larger feeding area than is covered by the extended cirri. Peduncles curved to place the capitulum near the sea-floor might even allow direct extraction of particles from the sediment surface.

Wide spacing of growth lines on the capitular plates suggests this barnacle grows quickly at Station GTVA 33. The lower proportions of breeding animals and the larger size of brooding specimens at GTVA 10 indicates poorer 
growth conditions there. Rapid growth could explain the apparently low abundance of small individuals and recruits compared with typical shallow water barnacle populations; less than $25 \%$ of our combined samples were below $12 \mathrm{~mm}$ capitulum size. There is no trace of endo- or ecto-symbiosis with bacteria that might help to support such growth or the high population densities. Gut contents indicate reliance on high flux of small particles, which could be free-living bacteria in the issuing vent fluids or detritus from the colonies of symbiont-containing clams. Further sampling of fluids and particulates is needed.

Reproduction appears to be continuous: individuals developing gametes and at different stages of brooding were present in all samples. Spring and summer were no different: March in 1994 and July in 1998. A larger number of Station 10 specimens were in the stage of gamete development, which may be a habitat rather than time effect. Population size structures give no suggestion of cohort recruitment. A long breeding season might account in part for the relatively small proportion of juveniles in the population. It is likely that the level of reproduction will vary with environmental conditions at different sites, as does growth.

The multiple origin of the larvae used in the culture experiments, probably released from different parents at varying times, complicated the tracking of developmental stages. In addition, the development of lecithotrophic larvae of barnacles may not always proceed in the typical distinct stages found in species with planktotrophic larvae, and any size change can be small (Anderson, 1965, 1986). However, Barnes \& Achituv (1981) reported six naupliar stages in Tetraclita rufotincta in which development occurs without feeding and in which the first nauplius stage measures $508 \mathrm{~mm}$ total length, slightly smaller than in Leucolepas longa. In Tesseropora pacifica, which also has lecithotrophic development, Crisp (1986) reported six naupliar stages. The larvae that developed in our cultures were quite similar in general appearance to the lecithotrophic larvae of Tesseropora pacifica (Crisp, 1986) and quite unlike the planktotrophic larvae of typical ocean surface lepadomorphs (Moyse, 1987; Walker et al., 1987).

Development of nauplii appeared to be quite slow at $4^{\circ} \mathrm{C}$, and only a few individuals in the cultures reached Stage IV. However, it is likely that there is continuation through two further stages to the cypris. At the end of 45 days' cultivation the nauplii still contained considerable lipid reserves, indicating the likelihood of more developmental stages and a potential for long distance dispersal. There is a possibility the nauplii could remain relatively dormant at near-bottom temperatures, 2.5 to $3.0^{\circ} \mathrm{C}$ in the New Ireland and Manus Basins (Gamo et al., 1993; Herzig \& Hannington, 1994), to be activated into faster growth and metamorphosis to the cyprid stage on encountering suitable environmental signals at vents or seeps (Pradillon et al., 2001). The lipid reserves may make the larvae buoyant, as observed at the surface, but lipid buoyancy changes under pressure (Yayanos et al., 1978) and the nauplii might remain demersal at the depths where the adults live.

The long developmental time suggests either that deepwater circulation patterns retain the larvae locally, or the Edison population can exchange propagules with unknown distant locations. Further exploration of the
Feni-Tabar island arc should locate more populations of these species and resolve the nature of the fluid emissions that support them.

Leucolepas longa forms a major component of the Edison sulphide habitat community: it represents the second greatest biomass in the collections after the clams. Its high densities depicted in bottom images suggests it plays a substantial role in capturing and retaining particles at the sea-floor over the seep/vent site. The relative importance of suspension feeders varies markedly among vent and seep habitats (Sibuet \& Olu, 1998; Giere et al., 2003). This second 'tier' in the Edison setting is unusually dense. The barnacle occurs where anemones, tubiculous polychaetes and shrimp are found as particle consumers in other hydrothermal systems. Several species of mobile crustaceans and molluscs probably benefit from the abundant faecal matter produced and the shelter that the stalks provide. Further work on the biology of other newly discovered lepadid barnacles will extend interpretation of the role of this taxon in sulphide-rich habitats.

This research was conducted on collections taken during cruises carried out by FS 'Sonne'. That of 1998 was funded by Bundesministerium für Bildung und Forschung, Germany, through grant no. 03G0133A to Freiberg University of Mining and Technology. V.T. gratefully acknowledges the invitation from Chief Scientist Peter Herzig and Mark Hannington to join this cruise. Thanks are due to I.R. Jonasson for the 1994 specimens. V.T. was funded by Natural Sciences and Engineering Research Council, Canada. A.J.S. was principal investigator, Natural Environment Research Council, Research grant no. GST/02/ $1478(1 / 5 / 1997$ to $31 / 3 / 2000)$, and gratefully acknowledges use of video, microscopic, and computing equipment provided by that grant. We thank T. Jellineck for continuing observations on larvae beyond the end of V.T.'s participation in the cruise, and C.L. Singla of the University of Victoria for the SEM studies. J. Rose and L. Franklin helped with figures.

\section{REFERENGES}

Anderson, D.T., 1965. Embryonic and larval development and segment formation in Ibla quadrivalvis Cuv. (Cirripedia). Australian Fournal of Zoology, 13, 1-15.

Anderson, D.T., 1986. The circumtropical barnacle Tetraclitella divisa (Nilsson-Cantell) (Balanomorpha, Tetraclitidae): cirral activity and larval development. Proceedings of the Linnean Society of New South Wales, 109, 107-116.

Barnes, M. \& Achituv, Y., 1981. The nauplius stages of the cirripede Tetraclita squamosa rufotincta Pilsbry. Fournal of Experimental Marine Biology and Ecology, 64, 149-165.

Beck, L.A., 1996. Morphology and anatomy of new species of neolepetopsid, acmaeid, fissurellid and pyropeltid limpets from Edison Seamount off Lihir Islands (West Pacific). (Gastropoda: Prosobranchia: Neolepetopsidae, Acmaeidae, Fissurellidae, Pyropeltidae). Archiv der Molluskenkund, 125, 87-103.

Binns, R.A., Parr, J.M., Gemmell, J.B., Whitford, D.J. \& Dean, J.A., 1997. Precious metals in barite-silica chimneys from Franklin Seamount, Woodlark Basin, Papua New Guinea. Marine Geology, 142, 110-141.

Bogdanov, Yu.A. et al., 1997. Low-temperature hydrothermal deposits of Franklin Seamount, Woodlark Basin, Papua New Guinea. Marine Geology, 142, 99-117.

Buckeridge, J.S., 2000. Neolepas osheai sp. nov., a new deep-sea vent barnacle (Cirripedia: Pedunculata) from the Brothers Caldera, south-west Pacific Ocean. New Zealand Fournal of Marine and Freshwater Research, 34, 409-418. 
Crisp, D.J., 1986. A comparison between the reproduction of high- and low-latitude barnacles, including Balanus balanoides and Tetraclita (Tesseropora) pacifica. In Biology of benthic marine organisms. Techniques and methods as applied to the Indian Ocean (ed. M.-F. Thompson et al.), pp. 69-84. Rotterdam: A.A. Balkema.

Desbruyères, D., Alayse-Danet, A.M. \& Ohta, S., 1994. Deepsea hydrothermal communities in southwestern Pacific backarc basins (the North Fiji and Lau Basins): Composition, microdistribution and food web. Marine Geology, 116, 227-242.

Galkin, S.V., 1997. Megafauna associated with hydrothermal vents in the Manus Back-arc Basin (Bismarck Sea) Marine Geology, 142, 197-206.

Gamo, T. et al., 1993. Hydrothermal plumes in the eastern Manus Basin, Bismarck Sea: $\mathrm{CH}_{4}, \mathrm{Mn}, \mathrm{Al}$, and $\mathrm{pH}$ anomalies. Deep-Sea Research I, 40, 2335-2349.

Giere, O., Borowski, C. \& Prieur, D., 2003. Biological productivity in hydrothermal systems. In Mass and energy fux through hydrothermal systems (ed. P. Halbach et al.), pp. 211-234. Berlin: Dahlem Press. [Dahlem Workshop Report, no. 89.]

Herzig, P.M. \& Hannington, M.D., 1994. Tectonics, petrology and hydrothermal processes in areas of alkaline island-arc volcanoes in the southwest Pacific. Cruise Report Sonne-94 BMFT FK 03G0094A0. Freiberg University of Mining and Technology, Germany.

Herzig, P.M. \& Hannington, M.D., 1995. Hydrothermal activity, vent fauna and submarine gold mineralization at alkaline forearc seamounts near Lihir Island, Papua New Guinea. In Proceedings of the 1995 PACRIM Congress, Auckland, NZ (ed. J.L. Mauk and J.D. St. George), pp. 279-284. Melbourne: Australasian Institute of Mining and Metallurgy.

Herzig, P. \& Hannington, M., 1998. Volcanism, hydrothermal processes and biological communities at shallow submarine volcanoes of the New Ireland fore-arc (Papua New Guinea). Cruise Report Sonne-133 BMBF FK 03GO133A. Freiberg University of Mining and Technology, Germany.

Hessler, R.R. \& Lonsdale, P., 1991. Biogeography of Mariana Trough hydrothermal vent communities. Deep-Sea Research, 38, 185-199.

Ikeya, N. \& Yamaguchi, T., 1993. UP Biology 93. Tokyo: University Press. [In Japanese.]

Jones, D.S., 1993. A new Neolepas (Cirripedia: Thoracica: Scalpellidae) from an abyssal hydrothermal vent, Southeast Pacific. Bulletin of Marine Science, 52, 937-948.

Moyse, J., 1987. Larvae of lepadomorph barnacles. Crustacean Issues, 5, 329-362.

Newman, W.A., 1979. A new scalpellid (Cirripedia); a Mesozoic relic living near an abyssal hydrothermal spring. Transactions of the San Diego Society of Natural History, 19, 153-167.

Newman, W.A., 1985. The abyssal hydrothermal vent invertebrate fauna: a glimpse of antiquity? Bulletin of the Biological Society of Washington, 6, 231-242.

Newman, W.A. \& Hessler, R.R., 1989. A new abyssal hydrothermal verrucomorphan (Cirripedia; Sessilia): the most primitive living sessile barnacle. Transactions of the San Diego Society of Natural History, 21, 221-235.

Newman, W.A. \& Yamaguchi, T., 1995. A new sessile barnacle (Cirripedia, Brachylepadomorpha) from the Lau-Arc Basin, Tonga; first record of a living representative since the Miocene. Bulletin du Muséum National d'Histoire Naturelle, Paris, Série 4, 17A, 221-243.

Ohta, S., 1990. Deep-sea submersible survey of the hydrothermal vent community on the northeastern slope of the Iheya Ridge, the Okinawa Trough. In The Sixth Symposium on Deep-Sea Research, pp. 145-156. Yokosuka: Japanese Marine Science and Technology Center.
Pradillon, F., Shillito, B., Young, C.M. \& Gaill, F., 2001. Development arrest in vent worm embryos. Nature, London, 413, 698-699.

Scott, S.D. \& Binns, R.A., 1995. Hydrothermal processes and contrasting styles of mineralization in the western Woodlark and eastern Manus basins of the western Pacific. In Hydrothermal vents and processes (ed. L.M. Parson et al.), pp. 191-205. London: Geological Society of London. Special Publication no. 87.

Sibuet, M. \& Olu, K., 1998. Biogeography, biodiversity and fluid dependence of deep-sea cold-seep communities at active and passive margins. Deep-sea Research, 45, 517-567.

Southward, A.J. \& Jones, D., 2003. A revision of stalked barnacles (Cirripedia: Thoracica: Scalpellomorpha: Eolepadidae: Neolepadinae) associated with hydrothermalism, including a description of a new genus and species from a volcanic seamount off Papua-New Guinea. Senckenbergiana Maritima, in press.

Southward, A.J. \& Newman, W.A., 1998. Ectosymbiosis between filamentous sulphur bacteria and a stalked barnacle (Scalpellomorpha, Neolepadinae) from the Lau Back Arc Basin, Tonga. Cahiers de Biologie Marine, 39, 259-262.

Southward, A.J., Newman, W.A., Tunnicliffe, V., Scheirer, D. \& Johnson, K., 1997. Biological indicators confirm hydrothermal venting on the Southeast Indian Ridge. BRIDGE Newsletter, 12, 35-39.

Southward, E.C. \& Galkin, S.V., 1997. A new vestimentiferan (Pogonophora: Obturata) from hydrothermal vent fields in the Manus Back-arc Basin (Bismarck Sea, Papua New Guinea, Southwest Pacific Ocean). Journal of Natural History, 31, 43-55.

Southward, E.C., Schulze, A. \& Tunnicliffe, V., 2002. Vestimentiferans (Pogonophora) in the Pacific and Indian Oceans: a new genus from Lihir Island (Papua New Guinea) and the Java Trench, with the first report of Arcovestia ivanovi from the North Fiji Basin. Fournal of Natural History, 36, 1179-1197.

Sysoev, A.V. \& Kantor, Yu.I., 1995. Two new species of Phymorynchus (Gastropoda, Conoidea, Conidae) from hydrothermal vents. Ruthenica, 5, 17-26.

Tufar, W., 1990. Modern hydrothermal activity, formation of complex massive sulphide deposits and associated vent communities in the Manus back-arc basin (Bismarck Sea, Papua New Guinea). Mitteilungen der Österreichen Geologisches Gesellschaft, 82, 183-210.

Walker, G., 1983. A study of the ovigerous frenae of barnacles. Proceedings of the Royal Society B, 218, 425-442.

Walker, G., Yule, A.B. \& Nott, J.A., 1987. Structure and function in balanomorph larvae. Crustacean Issues, 5, 307-328.

Yamaguchi, T. \& Newman, W.A., 1997a. Eochionelasmuis paquensis, new species (Cirripedia, Balanomorpha) from $17^{\circ} 25^{\prime} \mathrm{S}$, north of Easter Island: first record of a hydrothermal sessile barnacle from the East Pacific Rise. Fournal of Crustacean Biology, 17, $488-496$.

Yamaguchi, T. \& Newman, W.A., 1997b. The hydrothermal vent barnacles, Eochionelasmus from the North Fiji, Lau and Manus basins in the west Pacific. Zoosystema, 19, 623-649.

Yayanos, A.A., Benson, A.A. \& Nevenzel, J.C., 1978. The pressure-volume-temperature (PVT) properties of a lipid mixture from a marine copepod, Calanus plumchrus: implications for buoyancy and sound scattering. Deep Sea Research, 25, 257-268.

Zevina, G.B., 1981.'Usonogi raki podotryada Lepadomorpha (Cirripedia, Thoracica)' 1. Scalpellidae. Leningrad: Nauka.

Submitted 17 March 2003. Accepted 24 November 2003. 